\title{
The Smith-Mundt Act's Ban on Domestic Propaganda: An Analysis of the Cold War Statute Limiting Access to Public Diplomacy
}

\author{
Edward L. Carter \\ ed_carter@byu.edu
}

Allen W. Palmer

Follow this and additional works at: https://scholarsarchive.byu.edu/facpub

Part of the Communication Commons

\section{Original Publication Citation}

Palmer, Allen W., Carter, Edward L. "The Smith-Mundt Act's Ban on Domestic Propaganda: An Analysis of the Cold War Statute Limiting Access to Public Diplomacy." Communication Law and Policy (26).

\section{BYU ScholarsArchive Citation}

Carter, Edward L. and Palmer, Allen W., "The Smith-Mundt Act's Ban on Domestic Propaganda: An Analysis of the Cold War Statute Limiting Access to Public Diplomacy" (2006). Faculty Publications. 963.

https://scholarsarchive.byu.edu/facpub/963

This Peer-Reviewed Article is brought to you for free and open access by BYU ScholarsArchive. It has been accepted for inclusion in Faculty Publications by an authorized administrator of BYU ScholarsArchive. For more information, please contact ellen_amatangelo@byu.edu. 


\title{
Communication LaW AND Policy
}

\begin{tabular}{lll}
\hline Volume 11 & Winter 2006 & Number 1 \\
\hline
\end{tabular}

Copyright (c) 2006 Lawrence Erlbaum Associates, Inc.

\section{THE SMITH-MUNDT ACT'S BAN ON DOMESTIC PROPAGANDA: AN ANALYSIS OF THE COLD WAR STATUTE LIMITING ACCESS TO PUBLIC DIPLOMACY}

\author{
Allen W. PALMER* \\ EDWARD L. CARTER**
}

For more than fifty years, the U.S. Code has authorized the federal government to disseminate messages about America to international audiences. For at least thirty years, federal law has also prohibited those international propaganda messages from being disseminated within the United States. Given the realities of the acceleration and dispersion of information flow across international borders in the twenty-first century, a ban on dissemination of information that is tied to geographic boundaries raises both practical and policy issues. The domestic dissemination ban may have outlived its usefulness and relevance. Further, futile enforcement of the statute contradicts general U.S. policy promoting transparency and encouraging the free and open flow of information.

The communications revolution and the so-called "death of distance" have challenged many of the domestic presumptions behind the intent and consequences of government information, including

\footnotetext{
*Associate Professor and Director of International Media Studies, Department of Communications, Brigham Young University.

**Assistant Professor, Department of Communications, Brigham Young University.
} 
government speech and propaganda. ${ }^{1}$ The Smith-Mundt Act of $1948^{2}$ is a key statute outlining the global mission of U.S. propaganda abroad and limitations on distribution of U.S. propaganda at home. ${ }^{3}$ With the arrival of the Internet and the goal of universal access, the Smith-Mundt prohibition of domestic dissemination of the U.S. government's international propaganda materials appears to be particularly arcane and problematic. The role of new communication technologies in dismantling former laws and policies is an on-going political challenge, especially in terms of formal restrictions on the flow of information. 4 The unidimensional metaphor of "flow" has been revised to become "a space of flows" that transcends a "space of places" as the defining characteristic of post-Cold War world order. 5

The changes imposed by technology have entangled both government policies and legal history of government propaganda. Increasingly, the U.S. government's adherence to an outdated statute restricting the dissemination of international propaganda materials to its own citizens represents a contradiction with the United States' asserted belief in the right to send and receive information across international borders. As the United States attempts to spread democ-

${ }_{1}^{1}$ See generally Frances C. Cairncross, The Death of Distance: How the Communications Revolution Will Change OuR Lives (1997) (discussing the impact of technological advances on the spread of democracy, preservation of culture and other aspects of society).

2Pub. L. No. 80-402, 62 Stat. 6 (1948). The law's official title when enacted was the "United States Information and Educational Exchange Act" of 1948, but it has been popularly known as the "Smith-Mundt Act" because of its identification with sponsors H. Alexander Smith, a United States Senator from New Jersey, and Karl E. Mundt, a member of the United States House of Representatives from South Dakota.

${ }^{3}$ See generally Nancy E. Snow, Propaganda, InC.: Selling America's Culture TO THE WORLD (1998) (reviewing, from the perspective of a former U.S. Information Agency employee, the history and purposes of U.S. government propaganda to international audiences and noting the Smith-Mundt Act's ban on domestic dissemination).

${ }^{4}$ Parallel concerns were raised about the consequences of new satellite technologies for space law. The U.S. government championed the nondiscriminatory use of outer space in the United Nations debates over space policy, arguing against proposed restrictions by less-developed nations. For strategic security reasons, important questions about the rights and obligations of commercial satellite imaging, in particular, have never been clarified by statute. See Fred H. Cate, The First Amendment and the International "Free Flow" of Information, 20 VA. J. OF INT'L L. 372 (1990). See also Eleonora Ambrosetti, Remote Sensing From Outer Space: Its Significance and Problems From a Third World Perspective, 17 N.Y.U. J. OF INT'L L. \& Pol. 1 (1984); Allen W. Palmer, On the Limits of a Free Press: Remote Imaging and Commercial News Gathering, 49 GAZETTE: INT'L J. FOR COMM. STUDIES 159 (1992).

5 See Ronald J. Deibert, Altered Worlds: Social Forces in the Hypermedia Environment, in Digital Democracy: Politics AND Policy IN A Wired World 92-95 (Cynthia J. Alexander \& Leslie A. Pal eds., 1998). 
racy in Iraq and elsewhere, restricting information domestically undermines the strength of U.S. policies about the importance of transparency in government. As it continues to promote free flow of information abroad, the U.S. government's half-hearted commitment to domestic dissemination of certain government-sponsored information will be increasingly scrutinized and criticized. This issue is of importance not only for the policy objectives of the U.S. government but for the continued worldwide belief in the value of access to information as the basis for rational self governance.

Various scholars have examined the U.S. government's international propaganda efforts. For example, one writer chronicled the subversive radio activities of the U.S. government-primarily the Central Intelligence Agency-during World War II. ${ }^{6}$ Another researcher documented the international implications, including Cold War-related U.S. propaganda efforts overseas, of the American civil rights movement in the mid-20th century, ${ }^{7}$ and yet another wrote about the U.S. government's efforts to de-stabilize and culturally infiltrate Eastern Europe's Communist Party regimes during the early years of the Cold War. ${ }^{8}$ Other studies have focused on the impact of wartime propaganda and other government conduct on press free$\operatorname{dom}^{9}$ and on various aspects of twentieth century U.S. propaganda. ${ }^{10}$ Yet the literature on international U.S. propaganda has devoted very little attention to the Smith-Mundt Act's domestic dissemination ban. The researchers who have touched on the topic have not, for the most part, examined the impact of contemporary communication technologies and their policy implications.

This article examines the history and intent of the Smith-Mundt Act's prohibition of domestic dissemination of U.S. propaganda aimed at international audiences, and the subsequent creation of the U.S. Information Agency as the chief propaganda arm of govern-

\footnotetext{
${ }^{6}$ See LaWrence C. Soley, Radio Warfare: OSS AND CIA Subversive PROPAGANDA (1989).

${ }^{7}$ See Mary L. Dudziak, Cold War Civil Rights: Race and the Image of AMERICAN DEMOCRACY (2000).

${ }^{8}$ See Walter L. Hixson, Parting the Curtain: Propaganda, Culture, and the COLD WAR, 1945-1961 (1997).

${ }_{9}^{9}$ See Jeffery A. Smith, WAr and Press Freedom: The Problem of Prerogative POWER (1999).

${ }^{10}$ See Margaret A. Blanchard, Exporting the First Amendment (1986) (examining the post-World War II effort by U.S. journalists and others to foster free press rights around the world); Alvin A. SNYDER, WARRIORS OF Disinformation (1995) (retelling, from the perspective of the former director of U.S. Information Agency's Television and Film Service, propaganda activities directed primarily at the Soviet Union from 1982 to 1988).
} 
ment. 11 The article next discusses controversies in which litigants have challenged the domestic propaganda ban because, they assert, it violates statutory and constitutional provisions dealing with public access to government speech. It then examines cases from the $\mathrm{Su}$ preme Court of the United States addressing government speech in order to determine the extent to which the Constitution guarantees the government's right not to speak-at least to some audiences on some topics-when it so chooses. Next, it considers the extent of the right to receive in both U.S. and international jurisprudence. It concludes with observations about the continuing viability of the SmithMundt Act's domestic dissemination ban in light of the new reality of global information dissemination by Internet.

\section{Fighting to Keep Cold War Propaganda Battles Away FROM HOME}

International audiences have been the target of American propaganda 12 since Old World explorers discovered the New World. ${ }^{13}$ The

\footnotetext{
${ }^{11}$ For a firsthand account of the agency's history, see WILSON P. DIZARD, JR., Inventing Public Diplomacy: The Story of the U.S. Information Agency (2004).

${ }^{12}$ Our operational definition of propaganda is the one adopted by the Supreme Court in Meese v. Keene, 481 U.S. 465 (1987). In that case, the Court said political propaganda includes both "a form of slanted misleading speech that does not merit serious attention and that proceeds from a concern for advancing the narrow interests of the speaker rather than from a devotion to the truth" and "advocacy materials that are completely accurate and merit the closest attention and the highest respect." Id. at 477.

${ }^{13}$ See Julie Hedgepeth Williams, Printing in America, in THE MEDIA IN AMERICA: A HISTORY 17 (Wm. David Sloan \& James D. Startt eds., 1999) ("The printed word coaxed people to the New World, helped guide them there, and gave their presence there a sense of legitimacy and mission."). Even though the historical origins of propaganda have been traced to propagation of religious faith by the Roman Catholic Church as early as 1622, the concept of propaganda has more recently taken on political overtones. In 1842, W.T. Brande wrote that propaganda was "applied in modern political language as a term of reproach to secret associations for the spread of opinions and principles which are viewed by most governments with horror and aversion." T.H. QUALTER, PROPAGANDA AND PSYCHOLOGICAL WARFARE 4 (1962) (quoting W.T. Brande, Propaganda, in Dictionary of Science, Literature AND ART (1842) (page number unavailable)). Others have suggested that the rise of propaganda is the inevitable result of the rise of persuasion and public opinion in a modern technological society among mass publics. See, e.g., Jay Black, Semantics and Ethics of Propaganda, 16 J. OF MASs MEDIA ETHICS 121 (2001). For in-depth considerations of the role of propaganda in modern political communication, see generally Robert Cole, Propaganda in Twentieth Century War and Politics: AN ANNOTATED BIBLIOGRAPHY (1996) (listing and summarizing studies of government propaganda from around the world, beginning with World War I and proceeding through the Cold War); BRUCE LANNES SMith, HaRold D. LASSWELl \& RAlPH D.
} 
earliest American propaganda was not even created in America but was produced in Europe to entice European audiences to colonize North America, or at least to subsidize other colonists. ${ }^{14}$ French Huguenot Commander Jean Ribault traveled from Charlesfort, a settlement in present day South Carolina, to England in 1563 to raise funds for the settlement by promoting a book chronicling his adventures in Spanish Florida. ${ }^{15}$ A promotional book published in London in 1635 included a map, settlement guide, indentured servant contract and personal goods shipping form to entice would-be settlers to Maryland. 16

Throughout America's history, government propaganda has played a particularly high-profile role during wars and international political standoffs. For example, immediately after the United States entered World War I, President Woodrow Wilson established by executive order the Committee on Public Information. Headed by George Creel and assisted by the secretaries of State, War and Navy, the committee sought to influence both foreign and domestic public opinion in favor of the United States and against Germany. ${ }^{17}$ The committee has been widely criticized for its use of intellectuals and journalists "to sell an unpopular war to a dubious American public."18 The Creel Committee employed a full range of psychological and propaganda tactics, including promoting hatred toward Germans as enemies and monitoring of suspicious neighbors. Despite the criticism endured by the Committee on Public Information, the U.S. government during World War II once again created "an elaborate system of government censorship and publicity. ..."19 This time, the Office of War Information coordinated pro-

Casey, Propaganda, Communication, and Public Opinion (1946) (consisting of four essays and an extensive bibliography addressing not the tactics of government propaganda but rather its channels, communicators, contents and effect).

${ }^{14}$ See Williams, supra note 13, at 17.

15 See id. at 18.

${ }^{16}$ See id. at 19.

${ }_{17}$ See James D. Startt, The Media and National Crises, in ThE MediA IN AMERICA 319 (Wm. David Sloan \& James D. Startt eds., 1999). For more on the Committee on Public Information, see JAMEs R. MOCK \& CEDRIC LARSON, Words THAT Won THE War: The Story of the Committee on Public Information (1939); Stephen Vaughn, Holding Fast the InNer Lines: Democracy, Nationalism and the COMMITTEE ON PUBLIC INFORMATION (1980) (both chronicling the committee's activities and providing examples of its work, focusing on domestic propaganda efforts).

18 Joseph P. Bernt, Book Review, 77 Journalism \& MASs COMM. Q. 926 (2000) (reviewing Robert JaCKall \& Janice M. Hirota, Advertising, Public Relations, AND THE ETHOS OF ADVOCACY (2000)).

${ }^{19}$ Startt, supra note 17 , at 332. 
paganda activities in conjunction with the departments of Navy and War. ${ }^{20}$

By the end of World War II, many Americans held a negative perception of government propaganda not only because of censorship and misinformation by the American government but also because of the extensive anti-Jew and pro-Nazi propaganda disseminated in Germany throughout the 1930s. ${ }^{21}$ The prohibition of domestic dissemination of U.S. government propaganda may have grown out of the latent suspicion of Hitler's Germany,22 but the lingering distrust of government intentions was uniquely grounded in American democracy. Europeans, in general, were more tolerant of the idea of propaganda. Americans insisted that government efforts at persuasion at home, however, should remain benign, affirming their popular belief that government should not be the guardian of the public conscience, and that the electorate was capable of making rational choices free of undue influence from government itself: "In a dictatorship all propaganda is government propaganda; in a democracy there is great reluctance to allow the government to enter into the propaganda field at all."23 It was against this backdrop that Congress entered the international propaganda fray. ${ }^{24}$

Congress, aware of the controversy surrounding blatant propaganda efforts such as that conducted by the Committee on Public Information, looked to the State Department rather than the White House for a model international public relations program. ${ }^{25}$ In 1948,

${ }^{20} \mathrm{Id}$. at 334 .

${ }^{21}$ See id. at 333-34.

${ }^{22}$ See SNYDER, supra note 10, at 262 ("The Smith-Mundt Act was designed for another era, when the memory of Nazi propaganda was fresh.").

${ }^{23}$ QUALTER, supra note 13, at 122. Qualter asserted that the average citizen in a democracy does not object to political propaganda as such, unless it appears to be either dishonest or corrupt. Id. Democracies are filled with low-intensity propaganda that freely and fairly competes for public attention. More deliberate "pscyhological warfare," however, is viewed as inappropriate for domestic dissemination but may be directed abroad to interpret and explain U.S. policies, as long as it is designed to counter the unfavorable realities of international politics, including "hostile attempts to distort or frustrate the objectives and policies of the U.S." LT. COL. JOSEPH L. Cook, Nat'l War Coll., Public Diplomacy and Foreign Policy 16-17 (1985), available at http://www.ndu.edu/library/n3/SSP-85-030.pdf.

${ }^{24}$ For a detailed history of the legislative wrangling leading up to adoption of the Smith-Mundt Act, see Burton Paulu, The Smith-Mundt Act: A Legislative History, 30 JouRnalism Q. 300 (1953). See also Shawn J. Parry-Giles, Rhetorical Experimentation and the Cold War, 1947-1953: The Development of An Internationalist Approach to Propaganda, 80 Q. J. OF SpeEch 448 (1994) (discussing the Smith-Mundt Act and government propaganda with particular attention to the content of the United States' international propaganda messages produced between 1947 and 1953).

${ }^{25}$ S. REP. No. 80-811 (1948), reprinted in 1948 U.S. CODE CONG. SERV. at 1012 (noting the State Department's various programs in the 1930s to promote "scientific 
Congress passed the United States Information and Educational Exchange Act, or Smith-Mundt Act, "to promote a better understanding of the United States in other countries, and to increase mutual understanding between the people of the United States and the people of other countries." 26

The Smith-Mundt Act established exchange of students, professors, books and educational materials between the United States and other countries. 27 The act also authorized the federal governmentspecifically, the State Department28 — to employ its own agencies and private organizations to "disseminat[e] abroad ... information about the United States, its people, and its policies, through press, publications, radio, motion pictures, and other information media, and through information centers and instructors abroad." 29 This effort was necessary, Congress asserted, because America had shortsightedly failed to systematically promote itself to other nations, and by 1948 the United States was engaged in a massive and bitter propaganda war with the Soviet Union for the hearts and minds of the world:

From early days, American enterprise, skill, generosity, and zeal made great contributions to the life of other nations which have also enhanced the appreciation of the United States. Frequently, this projection of the United States required no special effort on our part, either as private citizens or as a government. The projection has often been haphazard. No one can estimate fully what differences a greater amount of persistent concern might have made in our foreign affairs. ...

and cultural cooperation" with Latin American nations and stating that those knowledge-exchange programs aimed to achieve "mutual welfare and security"). The U.S. Senate, in 1948, characterized the history of U.S. foreign relations as "a mixture of varying amounts of diplomacy, economics, social intercourse, and the diffusion of ideas." Id. at 1011.

${ }^{26} I d$. at 1011.

${ }^{27}$ United States Information and Educational Exchange Act of 1948, ch. 36, Title V, §§ 201-202 (Jan. 27, 1948).

28The U.S. Information Agency, the centerpiece of U.S. information diplomacy for forty-six years, was the successor of the Office of War Information, which functioned from 1942 to 1945 . USIA was formally created in 1953 and many of the international propaganda functions carried out in post-World War II by the Department of State were transferred to the agency at that time. The agency was dismantled in 1978 by President Jimmy Carter, with its mission assigned to the newly created International Communication Agency (ICA). The ICA was redesignated USIA in 1982 during the Reagan Administration. USIA was dissolved in 1999 and its international public relations functions were subsumed by the State Department.

${ }^{29}$ Information and Educational Exchange Act, supra note 27, at § 501. See also S. REP. No. 80-811 (1948), reprinted in 1948 U.S. CODE CONG. SERV. at 1016. 
The present hostile propaganda campaigns directed against democracy, human welfare, freedom, truth, and the United States, spearheaded by the Government of the Soviet Union and the Communist Parties throughout the world, call for urgent, forthright, and dynamic measures to disseminate truth. The truth can constitute a satisfactory counter-defense against actions which can only be described as psychological warfare against us as well as the purposes of the United Nations. ${ }^{30}$

That Congress viewed Smith-Mundt as an important tool in the ideological Cold War against the Soviet Union was underscored by the emphasis placed on vetting the loyalty of those who would work in the entities created by the Smith-Mundt Act. ${ }^{31}$ Both individual testimony before Congress and congressional committee reports show a strong concern for correcting "misinformation" and for telling the "truth" about the United States to international audiences. Then-Secretary of State George C. Marshall, for example, testified before the Senate Foreign Relations Committee of the need to disseminate abroad truthful information about the United States:

There is no question today that the policies and actions of the United States are often misunderstood and misrepresented abroad. The facts about the United States are withheld or falsified, and our motives are distorted. Our actions do not always speak for themselves unless the people of other countries have some understanding of the peaceful intention of our people. An understanding of our motives and our institutions can come only from a knowledge of the political principles which our history and traditions have evolved and of daily life in the United States. $^{32}$

Indeed, legislators portrayed the Smith-Mundt Act as nothing short of the guarantee of world peace without resorting to violence: "Words of truth can be most powerful weapons of peace if we use

\footnotetext{
${ }^{30}$ S. ReP. No. 80-811 (1948), reprinted in 1948 U.S. Code Cong. SERV. at 1011, 1013.

${ }^{31}$ See H. REP. No. 80-416, at 4 (May 21, 1947) ("It is essential that the personnel employed in the information and educational exchange program be individuals whose patriotism and loyalty is unquestioned. With the exception of officers of the Government appointed by the President and confirmed by the Senate, all individuals employed on this program must be certified as to loyalty and security by the Federal Bureau of Investigation.”). See also Information and Educational Exchange Act, supra note 27 , at $\$ 1001$.
}

${ }^{32}$ S. REP. No. 80-573, at 8 (1947). 
them properly and effectively. ... It is our conviction that a worldwide understanding of the real America will provide an environment which will contribute definitely to the maintenance of permanent peace. ..."33

The Smith-Mundt Act, however, not only promotes dissemination of truthful information, but it also restricts dissemination of government propaganda to Americans. As originally written in 1948, the act did not contain an explicit ban on domestic dissemination of U.S. propaganda. Rather, it authorized the Secretary of State to prepare and disseminate information about the United States through "press, publications, radio, motion pictures, and other information media[,]" and then provided:

Any such press release or radio script, on request, shall be available in the English language at the Department of State, at all reasonable times following its release as information abroad, for examination by representatives of United States press associations, newspapers, magazines, radio systems, and stations, and, on request, shall be made available to Members of Congress. ${ }^{34}$

There is evidence that legislators did not intend the original Smith-Mundt Act to prohibit domestic dissemination of propaganda. 35 Additionally, in the early 1970s, Sen. James L. Buckley ${ }^{36}$ of New York and Acting Attorney General Richard G. Kleindienst argued the act did not ban domestic dissemination. In 1972, Buckley obtained a copy of the U.S. propaganda film "Czechoslovakia 1968" and prepared to show it as part of his periodic televised reports on several New York television stations. Senate Foreign Relations Chair William Fulbright objected to Buckley's plan and asked the Justice Department to intervene. In a letter to Kleindienst dated March 28, 1972, Fulbright wrote: "The [U.S.] Information Agency

\footnotetext{
${ }^{33}$ H. REP. No. 80-416, at 8 (1947).

${ }^{34}$ United States Information and Educational Exchange Act of 1948, ch. 36, Title V, § 501 (Jan. 27, 1948).

${ }^{35}$ See S. REP. No. 92-754, at 82 (1972) ("The Smith-Mundt Act, the basic authority for [U.S. international propaganda], speaks only in terms of dissemination of information overseas, with the proviso that materials sent overseas be available for examination by the private media services and 'on request, shall be made available to Members of Congress"' (emphasis in original).).

${ }^{36}$ Senator Buckley was later appointed as a judge on the United States Court of Appeals for the District of Columbia Circuit, the same court which decided one of the most important federal cases involving the Smith-Mundt Act in 1998. See Essential Info., Inc. v. United States Info. Agency, 134 F.3d 1165 (D.C. Cir. 1998). Judge Buckley was not, however, among the three judges on the panel that heard that case.
} 
was created for the purpose of the dissemination abroad of information about the United States, its people, and policies. It was not created for dissemination of information in the United States."37

Kleindienst and the Justice Department, however, disagreed. In response to Fulbright's request, Kleindienst wrote that the Justice Department would not seek ajudicial restraining order against Buckley's broadcasts because such an action was not likely to succeed on the merits. Kleindienst reasoned that the Smith-Mundt Act's provision making U.S. propaganda materials available to news media representatives and members of Congress demonstrated legislative intent "to make USIA materials available to the American public, through the press and Members of Congress." 38 In response to Kleindienst's conclusion, Congress in 1972 amended the Smith-Mundt Act to include "a blanket provision barring [domestic] public distribution of any and all materials produced by the United States Information Agency." 39 Specifically, the act was amended to state that any U.S. propaganda materials prepared for international dissemination:

[S] hall not be disseminated within the United States, its territories, or possessions, but, on request, shall be available in the English language at the Department of State, at all reasonable times following its release as information abroad, for examination only by representatives of United States press associations, newspapers, magazines, radio systems, and stations, and by research students and scholars, and, on request, shall be made available for examination only to Members of Congress. ${ }^{40}$

Congress has tinkered with the language of the domestic dissemination ban several times. In 1985, a section was added to clarify that "no funds authorized to be appropriated to the United States Information Agency shall be used to influence public opinion in the United States, and no program material prepared by the United States Information Agency shall be distributed within the United States." 41 The basic idea behind the Smith-Mundt Act's domestic

37S. REP. No. 92-754, at 83 (1972).

${ }^{38}$ Id. at 84 .

${ }^{39} \mathrm{Id}$. at 85.

${ }^{40}$ Pub. L. No. 92-352, Title II, $§ 204$ (July 13, 1972) (codified at 22 U.S.C. § 1461).

${ }^{41}$ Pub. L. No. 99-93, Title II, § 208 (Aug. 16, 1985) (codified at 22 U.S.C. § 14611a). In 1994 a sentence was added: "The provisions of this section shall not prohibit the United States Information Agency from responding to inquiries from members of the public about its operations, policies, or programs." Pub. L. No. 103-236, Title II, § 232 (April 30, 1994) (codified at 22 U.S.C. § 1461-1a). 
dissemination ban was stated succinctly by Sen. Edward Zorinsky of Nebraska, who introduced the 1985 amendment: "The American taxpayer certainly does not need or want his tax dollars used to support U.S. Government propaganda directed at him or her." 42 In 1990, however, Congress acknowledged the interest in public access to government records by adding a provision that required the U.S. Information Agency to make international propaganda materials available for domestic distribution after twelve years. ${ }^{43}$ In 1995, reports circulated within USIA that U.S. commercial TV and radio operators were lobbying to retain the Smith-Mundt Act restrictions on domestic information in order to limit news competition between government and private news agencies. ${ }^{4}$

In 1999, President Bill Clinton issued a Presidential Decision Directive (PDD 68), which ordered the creation of an International Public Information (IPI) System. 45 The purpose of the IPI System is to influence foreign opinion toward a favorable view of U.S. foreign policy and to counteract anti-U.S. propaganda. 46 The IPI Core Group Charter "makes clear that IPI activities 'are overt and address foreign audiences only" and also states that "domestic information should be 'deconflicted' and 'synchronized' so as not to send a contradictory message." 47 Significantly, PDD 68 recognized the intent of the domestic ban of propaganda by Smith-Mundt, but stipulates:

[S]ince foreign media reports are frequently reflected in American news media, it will be impossible to entirely preclude a backwash of the IPI-generated information into America. The IPIG Charter recognizes this, calling for the US Government domestic public affairs activities to be coordinated with foreign IPI efforts. ${ }^{48}$

\footnotetext{
${ }^{42}$ See Gartner v. United States Info. Agency, 726 F. Supp. 1183, 1186 n.2 (S.D. Iowa 1989) (citing 131 Cong. Rec. 14945 (June 7, 1985)).

${ }^{43}$ Pub. L. No. 101-246, Title II, § 202 (Feb. 16, 1990) (codified at 22 U.S.C. $\S$ 1461(b)(1)).

${ }^{44}$ See James Love, Taxpayer Assets Project, The U.S. Information Agency ON THE INTERNET NOT FOR AMERICAN CITIZENS? (1995), at http://ists.essential.org/ 1995/info-policy-notes/msg00135.html.

45PDD 68 replaced National Security Decision Directive 77, "Management of Public Diplomacy Relative to National Security," issued by President Ronald Reagan on Feb. 14, 1983, at http://www.fas.org/irp/offdocs/nsdd/nsdd-077.htm.

${ }^{46}$ White House, Presidential Decision Directive 68, U.S. InTERnational INFORMATION POLICY (1999), at http://fas.org/irp/offdocs/pdd/pdd-68.htm.

${ }^{47}$ Ben Barber, Group Will Battle Propaganda Abroad; Intends to Gain Goreign Support for U.S., WASH. TIMES, July 28, 1999, at A1.

${ }^{48}$ PDD 68, supra note 46.
} 
Meanwhile, the proliferation of government agencies interested in both foreign and domestic communication has continued to expand. PDD 68 acknowledges "with the information revolution, all agencies now have the ability to communicate internationally." 49 Reports have circulated that government operatives were funded to carry out surreptitious propaganda assignments for U.S. intelligence agencies. ${ }^{50}$ In addition, news reports early in 2005 disclosed that several White House cabinet agencies, including Education and Health and Human Services, paid retainers to journalists and columnists to promote public acceptance of domestic government programs. 51

Despite the Smith-Mundt Act's ban on domestic dissemination of U.S. propaganda aimed at international audiences, Congress periodically exempted certain propaganda materials from the coverage of the act. In 1965, for example, Congress enacted a joint resolution "to permit the domestic release of a film on President Kennedy."52 Periodically, various proposals are made to exempt certain other U.S. propaganda from the domestic dissemination ban. ${ }^{53}$ The current version of the Smith-Mundt Act exempts two U.S. governmentproduced publications from the domestic dissemination ban: "Problems of Communism" and the "English Teaching Forum."54

With widespread use of the Internet, however, the domestic dissemination ban has become increasingly difficult to enforce or ratio-

\footnotetext{
${ }^{49} \mathrm{Id}$.

${ }^{50}$ One report suggests more than 800 news and public information organizations and individuals carried out propaganda assignments for the Central Intelligence Agency beginning in the 1950s. See Greg Guma, The World According to US, TOwARD FREedom OnLINE MAGAZINE, Summer 2004, at http://www.towardfreedom. com/index.htm.

51The Bush administration spent at least $\$ 88$ million in fiscal 2004 on contracts with major public relations firms, compared with $\$ 37$ million in 2001 . In all, the administration spent $\$ 250$ million on public relations contracts during its first term, compared with $\$ 128$ million spent for President Clinton between 1997 and 2000. See Jim Drinkard, Report: PR Spending Doubled Under Bush, USA TODAY (Jan. 26, 2005), available at http://www.usatoday.com/news/washington/2005-01-26-williams -usat x.htm.

${ }^{52} \bar{S} e e$ Gartner v. United States Info. Agency, 726 F. Supp. 1183, 1186 n.2 (S.D. Iowa 1989). See also S. REP. No. 92-754, at 83-84 (1972).

${ }^{5} \mathrm{See}$, e.g., Department of State Authorization Act, Fiscal Years 1986 and 1987, H.R. 2068, 99th Cong. (1985) (enacted as Foreign Relations Authorization Act, Fiscal Years 1986 and 1987, Pub. L. No. 99-93 (Aug. 16, 1985)) (Rep. Peter H. Kostmayer introduced House Amendment 43 on May 9, 1985, to exempt the U.S. Information Agency film Hal David: Expressing a Feeling, and Rep. Robert J. Lagomarsino introduced House Amendment 44 to exempt the U.S. Information Agency film Afghanistan 1982: The Struggle for Freedom Continues.).

5422 U.S.C. § 1461(a) (West Supp. 2005).
} 
nalize. 55 Internet services at the U.S. Information Agency were inaugurated in early 1994. Shortly afterward, the Washington Post pointed out that dissemination of USIA information on the Internet likely violated the Smith-Mundt Act because of potential access of the information within the United States: The USIA is "winking at those very fundamental mandates from the U.S. Congress. ... Just because it's on a computer, it doesn't mean that the basic rules don't apply."56 Agreeing with this sentiment, Senate Foreign Relations Committee Chair Jesse Helms pressed USIA to pull back its expanding Internet program. In response, USIA moved large volumes of information from electronic servers accessible to U.S. Internet users to other sites with addresses that were, ostensibly, "secret" from U.S. citizens. The USIA provided access to transcripts and audio files from its Voice of America (VOA) Web site, but the agency's staff responded to public inquiries by saying they could not legally tell the Web site address to Americans. 57

In the early 1990s, the negative term "propaganda" was recast as "public diplomacy" to characterize government information initiatives, including so-called "cultural diplomacy." Public diplomacy placed renewed emphasis on the Internet as a major propaganda tool to reach target publics. The mission was "to understand, inform, and influence foreign audiences and broaden the dialogue between American citizens and institutions and their counterparts abroad."58

Improvements in Internet programming and the World Wide Web continued to perplex managers in numerous government agencies about the practicality of Smith-Mundt in the new information marketplace. VOA's Web site contains this disclaimer: "The Voice of America does not broadcast in the United States. Our programs are intended for overseas audiences, as is our website."59 However, the Web disclaimer also affirms that for copyright purposes, "All text, audio and video material produced exclusively by the Voice of America is in the public domain." 60

\footnotetext{
${ }^{55}$ See Paul M. Schoenhard, Disclosure of Government Information Online: A New Approach From an Existing Framework, 15 HARV. J. L. \& TECH. 497 (2002); Thom Shanker \& Eric Schmitt, Pentagon Weighs Use of Deception in a Broad Area, N.Y. Times, Dec. 13, 2004, at A1.

56John Schwartz, Over the Net and Around the Law? U.S. Computer Users Gain Access to Voice of America Broadcasts, WASH. Post, Jan. 14, 1995, at C1.

${ }^{57}$ See LOVE, supra note 44.

${ }^{58}$ White House OfFice of the Press Secretary, Foreign AfFairs REORGANizATION FACT SHEet (1998), available at http://www.fas.org/news/usa/ 1998/12/98123003_tlt.html.

${ }^{59}$ Voice of America, at http://www.voanews.com/english/disclaim.cfm. ${ }^{60} \mathrm{Id}$.
} 
Government restructuring of the U.S. information services also raised questions about how to apply Smith-Mundt's provisions outside of the USIA. The Foreign Affairs Reform and Restructuring Act of $1998^{61}$ addressed how Smith-Mundt would be applied when USIA was integrated into the Department of State in 1999.62 On one hand, State held statutory responsibility for domestic communication to the American public about U.S. foreign policy; on the other, SmithMundt prohibited such activities for information functions of the former USIA. The Reform and Restructuring Act stipulated that none of the Smith-Mundt restrictions applicable to the USIA would apply to public affairs and information roles of the Secretary of State, except for public diplomacy programs carried out in foreign nations. ${ }^{63}$ Ironically, other provisions of the 1999 restructuring act provided for greater public transparency for planning and funding of public diplomacy initiatives in the State Department. 64

Government information disseminated overseas more recently shows some evidence of language-specific targets. For example, one reviewer noted that the English language Web site of the State Department's Office of International Information Programs, formerly USIA, contains different articles than companion Web sites in French and Spanish. The non-English sites contained more links to articles on human rights, especially in reference to abuses in Cuba and Peru, drugs and corruption, as well as reports with titles like

\footnotetext{
61Pub. L. No. 105-277, § 1333, 112 Stat. 2681 (1998).

62The Reform and Restructuring Act assimilated into the State Department USIA, United States Arms Control and Disarmament Agency, and the United States International Development Cooperation Agency.

${ }^{63}$ Pub. L. No. 105-277, § 1333, 112 Stat. 2681 (1998).

${ }^{64}$ When USIA was integrated into the State Department, the broadcasting functions of USIA were placed in a new independent agency, the International Broadcasting Bureau (IBB) to create a "firewall" between the State Department and the day-to-day operations of international broadcasting. Funding for all broadcasting initiatives is administered by the State Department and operational authority is exercised by a Broadcasting Board of Governors, appointed by the President and confirmed by the Senate. The Secretary of State has a seat on the board. The Research Branch of the former USIA, once known as the Office of Research and Media Reaction, is charged with ensuring that all government information is "asymmetric, based on research," and is now part of the Bureau of Intelligence and Research in the State Department. The office tracks foreign attitudes on a wide range of issues, including U.S. trade, armed conflicts, drugs, population, peace process and current issues and events. This research is distributed to foreign-policy interests at the White House, National Security Council and Department of Defense, as well as U.S. ambassadors and other foreign service personnel. See Rosaleen Smyth, Mapping U.S. Public Diplomacy in the 21st Century, 55 Australian J. OF INT'L AFFaIRS 421 (2001).
} 
"Towards a Community of Democracies" and "The World AIDS Epidemic," none of which appeared on the English site. 65

For its part, the U.S. military has attempted to clarify the boundaries of propaganda practices, including public affairs and civil affairs missions located in what they refer generally to as "information operations" (IO), including Psychological Operations (PSYOPS), Computer-Network Attack/Defense (CNA/CND), Electronic Warfare (EW), Operational Security (OPSEC), and Physical Destruction and Deception Operations. ${ }^{66}$

Public diplomacy initiatives to reach out to the Arab-speaking world have raised other perplexing issues regarding the statutory standing of the Smith-Mundt ban. Radio Sawa was launched to be an Arab-language radio service intended to promote U.S. interests in the Middle East, especially among younger audiences. Governed by the Broadcasting Board of Governors, Radio Sawa is programmed with both news and popular music. It is not clear, however, if the U.S. government's international propaganda broadcasts of popular American music (for example, such artists as Britney Spears and Eminem) would violate the Smith-Mundt Act's domestic dissemination ban if made in the United States. ${ }^{67}$

\section{Constitutional AND Statutory Challenges}

Legal challenges have been mounted against the domestic dissemination ban in the Smith-Mundt Act, but plaintiffs bringing these actions in the federal courts have largely been unsuccessful as both trial and appellate judges have declined the invitation to declare the act in conflict with either the First Amendment to the Constitution or the Freedom of Information Act. 68 These challenges, nevertheless, demonstrate the range of criticism which the domestic dissemination ban increasingly faces.

Attempts were made to find all published cases involving challenges to the Smith-Mundt Act's domestic dissemination ban. Methodology consisted of searches within Westlaw's electronic databases. First, the term "Smith-Mundt" was used in the Westlaw

\footnotetext{
${ }^{65}$ See Angela Maria Lungu, War.com: The Internet and Psychological Operations, 28 JOINT FORCES Q. 14-17 (Spring/Summer 2001).

${ }^{66}$ See BRAD M. WARD, U.S. ARMY WAR COLl., STRATEgIC INFluence OPERATIONS-THE INFORMATION CONNECTION 20-25 (2003), at http://www.fas.org/ irp/eprint/ward.pdf.

67 See George Gedda, Radio Sawa: Music as a Tool, Am. Foreign SERV. J. (Nov. 2002), available at, http://www.afsa.org/fsj/nov02/radio.pdf.

685 U.S.C. $§ 552$ et seq. (West Supp. 2005).
} 
"ALLFEDS" database, which contains all available federal court opinions beginning in the year 1790. Second, the Westlaw KeyCite function was used to determine all citing references, including published judicial opinions, to 22 U.S.C. $§ 1461-1 \mathrm{a}$, which contains the domestic dissemination ban. Together, the searches revealed three cases involving challenges to the Smith-Mundt Act's domestic dissemination ban that have resulted in published judicial opinions.

The first case was a First Amendment challenge to the SmithMundt Act brought by Michael Gartner 69 and The Ames (Iowa) Daily Tribune in the U.S. District Court for the Southern District of Iowa in 1989.70 The second case was a challenge to the Smith-Mundt Act under the Freedom of Information Act originating in the U.S. District Court for the District of Columbia and concluding in the U.S. Court of Appeals for the D.C. Circuit. ${ }^{71}$ These two cases are reviewed in detail herein. A third case, also brought in the U.S. District Court for the District of Columbia, was very similar to the second case in that it challenged the dissemination ban on Freedom of Information Act grounds. ${ }^{2}$ Given that the written opinion in the latter case largely mirrored the reasoning of the D.C. Circuit case reviewed at length below, only a brief treatment is given of the third case.

Gartner, The Ames Daily Tribune, and Iowa state legislator Ralph Rosenberg sued the U.S. Information Agency to obtain a declaratory judgment that the Smith-Mundt Act's domestic dissemination ban constituted a violation of their First Amendment speech rights. ${ }^{73}$ They contended that the ban prohibited them from either receiving or disseminating constitutionally protected information. ${ }^{74}$ With re-

${ }^{69}$ Both before and after the lawsuit described in this article, Gartner had a varied and highly distinguished career in journalism. He earned a juris doctorate from New York University and followed his grandfather and father into the newspaper industry. He was a reporter and editor at The Wall Street Journal, the Des Moines Register and other newspapers. He was president of NBC News-although his tenure there ended in controversy after the news organization admitted planting incendiary devices in vehicles undergoing crash tests-and the American Society of Newspaper Editors. In 1997, while serving as editor and part owner of The Daily Tribune in Ames, Iowa, Gartner was awarded a Pulitzer Prize for editorial writing. See S. Res. 7, 77th Gen. Assembly, Session 1 (Ia. 1997).

${ }^{70}$ Gartner v. United States Info. Agency, 726 F. Supp. 1183 (S.D. Iowa 1989).

71Essential Info., Inc. v. United States Info. Agency, 1996 WL 968472 (D. D.C. Nov. 27, 1996) (unpublished), aff'd 134 F.3d 1165. (D.C. Cir. 1998).

72Judicial Watch, Inc. v. United States Dept. of Commerce, 337 F. Supp. 2d 146 (D.D.C. 2004). The Department of Commerce successfully argued that the SmithMundt Act's domestic dissemination ban was an Exemption 3 statute under FOIA with respect to issues of the "Wireless File," a daily electronic news summary produced by the U.S. Information Agency. Id.

${ }^{73}$ Gartner, 726 F. Supp. at 1185.

${ }^{74} I d$. (citing plaintiffs' complaint). 
spect to the asserted right to receive government information, Gartner contended that his speech right was infringed when the U.S. Information Agency refused to allow him to photocopy materials that he was allowed to examine at the agency offices and to excerpt, without retribution, during a speech. ${ }^{75}$ Part of the plaintiffs' argument focused on Congress's attempt to "overrule" the Justice Department's 1972 determination, communicated to Fulbright by Kleindeinst, that the Smith-Mundt Act did not prohibit the domestic dissemination of propaganda materials intended for international audiences. ${ }^{76}$ The U.S. Information Agency, however, contended that it complied exactly with the Smith-Mundt Act by allowing Gartner, a press representative, to examine its materials, but not to photocopy or disseminate them.

The district court sided with the U.S. Information Agency, concluding that the First Amendment did not include a right "to make verbatim copies of USIA materials at USIA offices." 77 Citing an unpublished decision from the U.S. District Court for the Western District of Washington, the court concluded that such an expansive interpretation of the First Amendment was not appropriate because it would negate the need for the Freedom of Information Act:

Plaintiff's reading of the first amendment would seem to require the government to compile, transcribe, and make available to any requesting party any communication it makes to an outside person or persons. Carried to its logical end, plaintiff could conceivably compel disclosure of all intragovernmental communication and procedures as well. ${ }^{78}$

The First Amendment, the federal district court in Iowa concluded, may restrict the federal government from prohibiting a newspaper "from telling the news to their readers," but the speech and press clauses did not impose upon the government "a constitutional duty to supply the plaintiffs with the news to write about."79 This conclusion, the court held, was dictated by Supreme Court juris-

${ }^{75}$ Id. at 1192 .

${ }^{76} I d$. at 1194. Gartner and the other plaintiffs unsuccessfully argued that Congress's action to stop showings of U.S. Information Agency films such as the showing made by Sen. Buckley in New York was an unconstitutional attempt to bestow on the U.S. Information Agency the authority to censor speech.

${ }^{77} I d$. at 1190 .

78Id. at 1189 (citing Smith v. USIA, No. C 76-483 (W.D. Wash. 1978) (unpublished)) (emphasis in original).

${ }^{79} I d$. at 1188 . 
prudence: "The right to speak and publish does not carry with it the unrestrained right to gather information." 80

With respect to the second argument advanced by Gartner and the other plaintiffs, the court concluded that there had been no infringement on the right to disseminate constitutionally protected speech. Because Gartner and the other plaintiffs did not have a constitutional right to gain access to the U.S. Information Agency materials, and because the federal government had not censored nor otherwise restrained the plaintiffs' ability to say anything they desired, the court held that there was no basis on which to issue a declaratory judgment against the U.S. Information Agency and the case was dismissed in favor of the federal government. ${ }^{81}$ The district judge, however, did not resist the opportunity to observe that even though the federal government's conduct in conjunction with the Smith-Mundt Act was not unconstitutional under the First Amendment, "It would be easy to conclude that [the domestic dissemination ban] is 'inappropriate or even stupid[]'." 82 The district court's opinion was not appealed.

Subsequent legal challenges to the Smith-Mundt Act have focused not on asserted First Amendment problems but rather on purported conflicts with the Freedom of Information Act. For example, a group of researchers, scholars and journalists sought access under the Freedom of Information Act to the World Wide Web addresses of materials produced by the U.S. Information Agency. 83 The U.S. District Court for the District of Columbia held in 1996 that the SmithMundt Act's domestic dissemination ban constituted an exemption from the Freedom of Information Act's requirement of public disclosure, and the U.S. Court of Appeals for the D.C. Circuit in 1998 affirmed the district court judgment. 84

The plaintiffs contended that Congress could not have intended the Smith-Mundt Act to constitute an exception to the Freedom of Information Act because the result would be irrational: It "would al-

\footnotetext{
${ }^{80} I d$. at 1189 (quoting Zemel v. Rusk, 381 U.S. 1, 17 (1965)).

${ }^{81} \mathrm{Id}$. at 1195 (holding that the plaintiffs lacked standing because they had failed to establish "a concrete, factual controversy to invoke the jurisdiction of the courts," despite the plaintiffs' arguments that (1) they risked sanctions by violating the Smith-Mundt Act, (2) their speech had been chilled, (3) the government had engaged in prior restraint of speech and (4) Congress intended to regulate speech when it amended the Smith-Mundt Act in 1972 to provide for an explicit domestic dissemination ban).

${ }^{82} I d$. at 1195

${ }^{83}$ Essential Info., Inc. v. United States Info. Agency, 134 F.3d 1165 (D.C. Cir. 1998).

${ }^{84} \mathrm{Id}$. at 1169.
} 
low some United States residents, such as those close to a national border or with friends abroad, to obtain USIA records while denying other residents access to them." 85 The court acknowledged that, in the age of the Internet, the domestic dissemination ban would not effectively result in U.S. propaganda materials being kept out of the hands of U.S. residents. ${ }^{86}$ Nevertheless, two of the three D.C. Circuit judges on the panel concluded that Congress had clearly expressed its intent in the Smith-Mundt Act that propaganda materials not be disseminated domestically, and therefore materials subject to the act were exempt from the Freedom of Information Act's disclosure provisions. ${ }^{87}$ The Smith-Mundt Act, the court concluded, came within Freedom of Information Act Exemption 3, which "shields from the general disclosure requirement "matters that ... are exempted from disclosure by statute. ..." 88

One of the judges who joined the court's majority, Karen LeCraft Henderson, wrote a concurring opinion arguing that Congress, in the Smith-Mundt Act, struck an appropriate balance between prohibiting unwanted domestic propaganda and allowing public access to government-produced materials. 89 Judge Henderson recognized that the Smith-Mundt Act was not just a nondisclosure statute (that is, a statute prohibiting domestic dissemination of propaganda) but it also was a disclosure statute because it contained provisions providing for examination of propaganda materials by members of Congress and of the press and because it required propaganda materials to be made publicly available twelve years after their initial preparation or dissemination. 90

The third judge on the panel, Judge David S. Tatel, dissented from the majority opinion because he disagreed that the Smith-Mundt Act specifically exempted propaganda materials from public disclosure. ${ }^{91}$ Rather, Judge Tatel wrote, the Smith-Mundt Act expansively promotes dissemination of official government propaganda. With advances in technology brought by not just the Internet but also satellite television, Judge Tatel said, the U.S. government's propaganda efforts are not unknown inside the United States:

${ }^{85} \mathrm{Id}$. at 1168 .

${ }^{86}$ Id. at 1168-69 (acknowledging that "in some cases individuals within the United States will be able to obtain access to the information disseminated").

${ }^{87} I d$. at 1169.

${ }^{88} I d$. at 1166 (quoting 5 U.S.C. $\$ 552(\mathrm{~b})(3)(\mathrm{B})$ ).

${ }^{89} \mathrm{Id}$. at 1170 (Henderson, J., concurring).

${ }^{90} \mathrm{Id}$. at 1169-70 (Henderson, J., concurring).

${ }^{91} I d$. at 1170 (Tatel, J., dissenting). 
Residents of southern Florida can receive Radio Marti and TV Marti broadcasts, owners of satellite dishes anywhere in the United States can receive Worldnet television, domestic computer users can find materials intended for foreign audiences on the agency's web pages, and people anywhere in the country can ask friends overseas to obtain USIA program materials for their own domestic use, but under today's decision, these same people cannot obtain precisely the same information through FOIA. ${ }^{92}$

Judge Tatel concluded that there was a material difference between the Smith-Mundt's ban on domestic dissemination of propaganda and a passive government response to a Freedom of Information Act request. Because the latter disclosure would not carry the same imprimatur of government propaganda- with the attendant implication of an improper influence on public opinion- as the former dissemination, Judge Tatel would have held that the government should be required to publicly disclose its propaganda materials through the Freedom of Information Act even while continuing to comply with the domestic dissemination ban in the Smith-Mundt Act. 93

In 2004, the U.S. District Court for the District of Columbia was confronted with another case ${ }^{94}$ in which the government argued that the Smith-Mundt Act's domestic dissemination ban constituted an exception to the Freedom of Information Act's disclosure requirements because any government materials covered by Smith-Mundt were "specifically exempted from disclosure by statute."95 A public interest group sought disclosure under FOIA of government documents including records related to international trade missions of the former Commerce Secretary Ron Brown. Among the records sought were editions of the "Wireless File,"96 a daily news service distributed internationally by the U.S. Information Agency. The dis-

\footnotetext{
${ }^{92} I d$. (Tatel, J., dissenting).

${ }^{93} \mathrm{Id}$. at 1171-72 (Tatel, J., dissenting).

94Judicial Watch, Inc. v. United States Dept. of Commerce, 337 F. Supp. 2d 146 (D.D.C. 2004).

${ }^{95}$ See 5 U.S.C. $§ 552(b)(3)$ (West Supp. 2004).

96 One author described the "Wireless File":

The WIRELESS FILE is a daily text based press service, disseminated in five languages, linked by computerized communication systems to all overseas USIA posts. The Wireless File provides time sensitive information, including full transcripts of speeches, press conferences, Congressional testimony, etc., and texts of published articles and interviews.
}

Love, supra note 44. 
trict judge agreed with the argument of the government that the Smith-Mundt's explicit domestic dissemination ban constituted an exemption from FOIA. 97

\section{CONTEMPORARY PROBLEMS IN GOVERNMENT SPEECH THEORY}

In the Gartner case, the district court alluded to the concept that when the government speaks, the First Amendment is not implicated. 98 In other words, Congress and the other branches of government have virtually unrestricted authority to determine the content and extent of the federal government's speech, and those determinations are not subject to judicial challenge. This idea finds support in the decisions of intermediate federal appellate courts ${ }^{99}$ and, increasingly, the Supreme Court.

Concerning the government's right to speak and not speak, and the status of a right to receive government information, scholars have considered various ways in which government speech fits within First Amendment jurisprudence, but these research efforts have not focused on the domestic dissemination ban in the SmithMundt Act. One scholar concluded that government speech was particularly problematic when it concerned "unsettled issues" in society 100 and that government speech was most defensible when it constituted one voice among many, when it did not coerce and when it did not monopolize discussion. 101 A scholar concluded that the government's systematic use of "deceptive, manipulative language to influence the American people on matters of nuclear strategy and weaponry" justified legislative and judicial limits on government speech. ${ }^{102}$ Another scholar argued for the existence of constitutional

\footnotetext{
97Judicial Watch, 337 F. Supp. 2d at 168 ("Consistent with the Smith-Mundt Act, the DOC withheld five editions of the United States Information Agency's 'Wireless File,' a daily electronic news service disseminated abroad, and each edition's table of contents.").

${ }^{98}$ Gartner v. United States Info. Agency, 726 F. Supp. 1183, 1189 (S.D. Iowa 1989).

${ }^{99}$ See, e.g., Gregg v. Barrett, 771 F.2d 539 (D.C. Cir. 1985) (rejecting a constitutional challenge to the congressional practice of altering the content of speeches made on the floors of the Senate and House, respectively, before they are published in the Congressional Record because Congress has the right to determine the content of its own speech).

${ }^{100 A b n e r ~ S . ~ G r e e n e, ~ G o v e r n m e n t ~ S p e e c h ~ o n ~ U n s e t t l e d ~ I s s u e s, ~} 69$ FORDHAM L. REV. 1667 (2001).

${ }^{101}$ Abner S. Greene, Government of the Good, 53 VAND. L. REV. 1 (2000).

${ }^{102}$ Richard Delgado, The Language of the Arms Race: Should The People Limit Government Speech?, 64 Boston U. L. REV. 961, 1001 (1984).
} 
limits on government speech, which was perceived to threaten discourse on issues of public concern. ${ }^{103}$ Other scholars have explored various approaches to measuring the constitutionality of government subsidies that impact speech. 104

\section{Government Speech Right}

In a series of opinions during the last twenty years, the Supreme Court has increasingly suggested that the federal government has an unrestricted right to determine the content of its own speech, even if that determination has the effect of overwhelming or compelling private speech. ${ }^{105}$ For example, in Meese $v$. Keene ${ }^{106}$ the Court concluded that the First Amendment did not prohibit Congress from requiring certain foreign filmmakers to label their films as "political

\footnotetext{
${ }^{103}$ Steven Shiffrin, Government Speech, 27 UCLA L. Rev. 514 (1980) (proposing an "eclectic approach" to limiting government speech that would essentially employ balancing to weigh the government interest in expressing a message against the potential harm to the public discourse).

${ }_{104}$ See Robert C. Post, Essay, Subsidized Speech, 106 YALE L. J. 151, 194-95 (1996) (advocating close examination of the "actual values that move our constitutional decisionmaking" and then proposing a two-step process: (1) categorizing speech as within public discourse, or in some other domain such as commerce; and (2) characterizing government action as either regulation, which would be subject to stringent constitutional standards, or "internal directives," in which the government would be afforded more latitutde); Martin H. Redish \& Daryl I. Kessler, Government Subsidies and Free Expression, 80 MINN. L. REV. 543 (1996) (advocating a system based on "a prior balancing").

105See, e.g., Rosenberger v. Rector \& Visitors of Univ. of Va., 515 U.S. 819, 833 (1995) ("[W]e have permitted the government to regulate the content of what is or is not expressed when it is the speaker or when it enlists private entities to convey its own message.").

106481 U.S. 465 (1987). The Foreign Agents Registration Act of 1938, 22 U.S.C. $\S$ 611-621, which was at issue in the Meese case, is fraught with irony when one considers it in light of the government's promulgation and defense of the Smith-Mundt Act. For example, the Foreign Agents Registration Act requires that foreign films that "contain political material intended to influence the foreign policies of the United States" be registered and labeled as "political propaganda." Meese, 481 U.S. at 470 . Yet there is no indication that similar propaganda materials produced by the United States and intended to influence the foreign policies of other nations are labeled as propaganda for the benefit of the citizens of those countries who may want to make decisions about the source and credibility of the information. Also, the Supreme Court in Meese reasoned that the political propaganda label was not constitutionally suspect in part because it did not restrain speech but rather resulted in more speech. The Court, in interpreting congressional motives, stated that the drafters of the Foreign Agents Registration Act believed "that the best remedy for misleading or inaccurate speech contained within materials subject to the Act is fair, truthful, and accurate speech." Id. at 481. Yet Congress apparently did not operate under the same belief when it adopted the Smith-Mundt Act, which results not in more speech being communicated to American citizens but rather less speech.
} 
propaganda," even though the filmmakers argued the mandatory labels infringed their own speech rights by discouraging potential viewers. The Meese Court stated that it had "no occasion here to decide the permissible scope of Congress' 'right to speak'[.]"107 Interestingly, most of the cases in which the Supreme Court has made recent statements about the government speech right were not cases in which the government's right to speak was at issue; thus, most of the Court's statements about government speech constitute dicta. ${ }^{108}$ The Court, however, has indicated that it may be willing to treat some of the dicta as binding precedent. 109

Aside from the jurisprudential problem of relying on dicta to make sweeping statements about the state of binding precedent, the Supreme Court's government speech doctrine suffers from several other serious deficiencies. First, the Court has not yet clarified the definition of government speech. Instead, the Court has contributed

${ }^{107} I d$. at 484 .

${ }^{108}$ See Legal Servs. Corp. v. Velazquez, 531 U.S. 533 (2001) (government-funded lawyers working on behalf of indigent clients were not government speakers and, therefore, the lawyers' speech could not be regulated in a viewpoint discriminatory way); United Foods v. United States, 533 U.S. 405 (2001) (government did not argue that it was engaging in speech when it enacted and enforced regulatory scheme requiring food producers to contribute money for generic advertising); Bd. of Regents of Univ. of Wisconsin v. Southworth, 529 U.S. 217 (2000) (public university did not engage in government speech when it provided mandatory student activity fees to students for speech not controlled by university); Glickman v. Wileman Bros. \& Elliott, Inc., 521 U.S. 457 (1997) (government did not argue that it was engaging in speech when it enacted and enforced regulatory scheme requiring food producers to contribute money for generic advertising); Rosenberger, 515 U.S. 819 (1995) (public university did not engage in government speech when it provided funds to operate a forum for expression of a diversity of viewpoints through student activities); Keller v. State Bar of Calif., 496 U.S. 1 (1990) (California bar association did not engage in government speech when it used lawyers' bar dues to convey certain messages). But cf. Rust v. Sullivan, 500 U.S. 173 (1991) (government-funded doctors providing family planning counseling were government speakers and, therefore, the doctors' speech could be regulated in a viewpoint discriminatory way).

${ }^{109}$ For example, in Legal Services Corp., the Court relied on dicta from Southworth to support the conclusion that "viewpoint-based funding decisions can be sustained in instances in which the government is itself the speaker ..." 531 U.S. at 541 (citing Southworth, 529 U.S. at 229). However, the citation to Southworth does not provid support in the form of binding precedent because Southworth was not a case involving government speech. See Southworth, 529 U.S. at 229 (stating that "[t]he University ... disclaimed that the speech is its own. ..."). Should the Supreme Court indeed choose to treat dicta as mandatory authority, the Court would apparently violate the principle that precedent is the attachment of "a specific legal consequence to a detailed set of facts in an adjudged case or judicial decision, which is then considered as furnishing the rule for the determination of a subsequent case ...” Allegheny County Gen. Hosp. v. NLRB, 608 F.2d 965, 969-70 (3d Cir. 1979) (footnote omitted). See also Roscoe Pound, Remarks on Status of the Rule of Judicial Precedent, 14 U. CIN. L. REV. 328-332 (1940). 
to the confusion about the definition of government speech by distinguishing the facts of two cases that are seemingly indistinguishable. In Rust $v$. Sullivan, the Court concluded that Congress did not violate the First Amendment when it allocated funds for family planning services but prohibited the funds from being used in "programs where abortion is a method of family planning." 110 While the Rust Court did not explicitly describe the family planning funding decision as government speech, it nevertheless stated that "when the Government appropriates public funds to establish a program it is entitled to define the limits of that program."111 In subsequent opinions, however, the Court described Rust as a case in which the government had engaged in its own speech, which was not subject to restriction by the First Amendment or, apparently, any other federal constitutional or statutory provision. ${ }^{112}$

Ten years after Rust, the Court was confronted with very similar facts but oddly came up with a very different result. In Legal Services Corp. $v$. Velazquez, 113 Congress had allocated funds for private lawyers to provide legal services to the indigent, but Congress also had specified that those funds could not be used to challenge existing welfare law. Although it would seem to follow from the Court's decision in Rust that the government-funded lawyers for the indigent, like the government-funded family planning doctors, were engaging in government speech and were thus subject to the government's restrictions on the content of that speech, the Court concluded otherwise. The Legal Services Corp. Court said that the lawyers for the indigent were not engaging in government speech at all and, therefore, the funding limitation against welfare law challenges was unconstitutional. ${ }^{114}$ The Court did not satisfactorily explain how the speech in Rust differed from that in Legal Services Corp. ${ }^{115}$

\footnotetext{
110500 U.S. at 178 (quoting 42 U.S.C. $\$ 300 \mathrm{a}-6$ ).

${ }^{111} I d$. at 194 .

${ }^{112}$ See, e.g., Rosenberger, 515 U.S. at 833 (stating that Rust stood for the propositions that "when the government appropriates public funds to promote a particular policy of its own it is entitled to say what it wishes" and "[w]hen the government disburses public funds to private entities to convey a governmental message, it may take legitimate and appropriate steps to ensure that its message is neither garbled nor distorted by the grantee").

113531 U.S. 533 (2001).

${ }^{114} I d$. at $540-49$.

${ }^{115}$ The Court in Legal Services Corp. seemed particularly concerned about the funding limitation's effect on the functioning of the judiciary system, and perhaps that is the best explanation for the distinction between the two cases. See Legal Services Corp., 531 U.S. at 548 ("The attempted restriction is designed to insulate the Government's interpretation of the Constitution from judicial challenge. The Constitution does not permit the Government to confine litigants and their attorneys in
} 
Beyond the problems of precedent and definition, the Supreme Court's government speech doctrine carries with it an even more fundamental and potentially dangerous problem: Its limits have not been drawn. The Court at times has suggested that there may be no constitutional or statutory limits on the government's speech right other than the political process: "When the government speaks, for instance to promote its own policies or to advance a particular idea, it is, in the end, accountable to the electorate and the political process for its advocacy. If the citizenry objects, newly elected officials later could espouse some different or contrary position."116

In May 2005, the Supreme Court held in Johanns v. Livestock Marketing Association 117 that a government-compelled subsidy used to produce generic beef advertisements was not subject to a First Amendment challenge because it constituted the government's own speech. In an opinion joined by five justices, Antonin Scalia wrote that the compelled subsidies of government speech were unrestricted by the First Amendment, 118 even though the individuals required to pay the subsidy disagreed with the message expressed. But the Johanns majority did not provide clear guidelines for defining government speech. The Court analyzed some aspects of lower court tests for defining government speech-such as control of and responsibility for the speech, funding source for the speech, and nexus between the message and the actual speaker-but the definitional contours of government speech largely remain to be drawn. 119

If the government's speech right indeed extends without limits except those that could be effected through change of representation by the electorate, then the government could readily overwhelm or compel a significant amount of private speech before voters get worked up enough to take the next opportunity to elect new representatives. Scholars have noted the potential for damage to First Amendment interests posed by the government's speech power and authority in

this manner. We must be vigilant when Congress imposes rules and conditions which in effect insulate its own laws from legitimate judicial challenge.").

${ }^{116} \mathrm{Bd}$. of Regents of Univ. of Wisconsin v. Southworth, 529 U.S. 217, 235 (2000). The seed of this thought was planted at least as early as 1977 by Justice Lewis Powell, who wrote a footnote that has been often cited in this context: "But the reason for permitting the government to compel the payment of taxes and to spend money on controversial projects is that the government is representative of the people.” Abood v. Detroit Bd. of Educ., 431 U.S. 209, 259 n.13 (1977) (Powell, J., concurring).

117125 S.Ct. 2055 (2005).

118Id. at 2062.

${ }^{119}$ See Edward L. Carter, Defining Government Speech: Recent Approaches and the Germaneness Principle, 82 Journalism \& MASs Comm. Q. 398 (2005). 
the areas of, among others, public education of school children, public policy on issues of general public concern and wartime propaganda. ${ }^{120}$ That the government's speech poses pitfalls was underscored by the 2005 discovery that the Bush Administration had quietly paid political commentators hundreds of thousands of dollars to promote administration objectives in print or over the public airwaves. ${ }^{121}$ With respect to wartime propaganda, specifically George Creel's World War I Committee on Public Information, it has been suggested that "[h] undreds of thousands of potential critics of American entry into World War I ... may not have been deterred from speaking out by the fear of prosecution; it may be, rather, that they were taken in and their judgment distorted by an omnipresent campaign of persuasion and information."122

If the extent of the government's right to speak equals or exceeds that of other speakers, then the government could argue that it also has the constitutional right not to speak when it so chooses. There is some jurisprudential basis for the idea that the First Amendment right to speak also includes the right not to speak. ${ }^{123}$ With the SmithMundt Act, however, Congress has not chosen merely not to speak. Instead, Congress has chosen to express a message about the United States but to allow its communication only to certain audiences (those outside the United States) while restricting its communication to other would-be listeners (those inside the United States). Even if the government has an unrestricted right to choose the content of its own messages, this selective communication raises basic

\footnotetext{
${ }^{120}$ See, e.g., Mark G. Yudof, When Government Speaks: Politics, LAW AND GOVERNMENT EXPRESSION IN AMERICA 51-66 (1983).

${ }^{121}$ See Howard Kurtz, Bush Urges End to Contracts with Commentators, WASH. Post, Jan. 27, 2005, at A4 (reporting that the Bush Administration spent $\$ 88$ million in 2004 for contracts with public relations firms, and part of that money went to conservative commentator Armstrong Williams to tout the No Child Left Behind Act and to syndicated columnist Maggie Gallagher to perform work related to the administration's "healthy marriage" initiative, at the same time Gallagher wrote columns about marriage).

122 YUDOF, supra note 120, at 66.

${ }^{123}$ See, e.g., McIntyre v. Ohio Elections Comm'n, 514 U.S. 334, 342 (1995) (“[A]n author's decision to remain anonymous, like other decisions concerning omissions or additions to the content of a publication, is an aspect of the freedom of speech protected by the First Amendment."); Rubin v. Coors Brewing Co., 514 U.S. 476, 492 (1995) (Stevens, J., concurring) ("The First Amendment generally protects the right not to speak as well as the right to speak."); Pacific Gas \& Elec. Co. v. Public Utilities Comm'n of Calif., 475 U.S. 1, 32 (1986) (Rehnquist, J., dissenting) ("This Court has recognized that natural persons enjoy negative free speech rights because of their interest in self-expression; an individual's right not to speak or to associate with the speech of others is a component of the broader constitutional interest of natural persons in freedom of conscience.").
} 
issues of fairness if not legally cognizable questions of equal protection denials under the Fourteenth Amendment. Furthermore, as discussed below, the selective restriction of U.S. government messages produced at the expense of U.S. taxpayers may not square with international concepts of the right of access to information. ${ }^{124}$

\section{Right to Receive Information}

With regard to the right to receive information, the United States sends mixed messages. On one hand, the United States was an early promoter of "[r]emoving barriers to global information flows," beginning in the 1940 s. ${ }^{125}$ The U.S. advocacy of a broad right to send and receive information across international borders was so vigorous and pervasive that, at one time or another, "almost every other country on earth" resisted the movement because of perceived violations of national sovereignty interests. ${ }^{126}$ Despite this resistance, the U.S.led effort to guarantee information flow across international boundaries has been largely successful:

Open information flow is now routinely accepted, both as a concept and as a pragmatic benefit by most industrial democracies and by a growing number of Third World economies. Many barriers remain but the trend is powerfully towards reducing them, largely because of pressures to make national economies more competitive in an informationdriven world marketplace. Another pressure, less measurable but equally important, comes from ordinary men and women who want to be linked to the new networks, whether it involves an ordinary telephone call or access to a high-technology database. ${ }^{127}$

The United States has been credited with giving an "ideological base" to the right to send and receive information, as expressed in

\footnotetext{
${ }^{124}$ But cf. Branzburg v. Hayes, 408 U.S. 665, 681, 707 (1972) (stating that "news gathering is not without its First Amendment protections" and "without some protection for seeking out the news, freedom of press could be eviscerated" but declining to protect journalists from subpoenas seeking information gathered from confidential sources).

${ }^{125}$ Wilson P. Dizard, Digital Diplomacy: U.S. Foreign Policy in the INFORMATION AGE 73 (2001).

${ }^{126} I d$. ("American advocacy of open information flow challenges long-standing claims of national sovereignty, in particular a government's right to control communications channels and the information they transmit. This U.S. stance is often seen by foreign governments as interference in their internal affairs, a high-handed attempt to extend First Amendment principles and practices to the rest of the world.").

${ }^{127} I d$. at 74 .
} 
the 1948 U.N. Declaration of Human Rights. ${ }^{128}$ There are also expressions of the right to receive information in U.S. statutory and case law. ${ }^{129}$ Given the United States' role in crafting and promoting the right to send and receive information across international borders, it is ironic that the U.S. government has for thirty years restricted itself in the information it can provide to its own citizens in accordance with the Smith-Mundt Act's domestic dissemination ban. 130

The Supreme Court has variously stated that the First Amendment does and does not protect a right to receive information. For example, in reviewing the case of a man who was convicted of possession of obscene material in the privacy of his own home, the Supreme Court said in 1969 that "[i]t is now well established that the Constitution protects the right to receive information and ideas."131 In that case, the Court went on to say that this right to receive information was protected regardless of the "social worth" of the information. 132 The contours of this right to receive information, however, have been little explored in Supreme Court opinions, and the Court has said in other contexts that there was no right to gain access to government property and government-controlled information. For example, in rejecting the argument of a broadcaster who had been denied access to a county jail, the Court said in 1978 that there existed "no basis for the claim that the First Amendment compels others-private persons or governments-to supply information."133

International human rights instruments clarify that the right to freedom of expression includes the right to receive information. Arti-

\footnotetext{
${ }^{128} \mathrm{Id}$. at 92 ("The overall effort to reduce global barriers to information flow has been a singular achievement of American digital diplomacy.”).

${ }^{129}$ See Charles F. Gormly, Comment, The United States Information Agency Domestic Dissemination Ban: Arguments for Repeal, 9 ADMIN. L. J. AM. U. 191, 209-11 (1995). The United States "defended the principle of free flow to the point of withdrawing [in 1984] from UNESCO, the U.N. agency with authority over international communications policy." Id. at 210. Additionally, the International Broadcast Act of 1994, Pub. L. No. 103236 (1994), stated that "it is the policy of the United States to promote the right of freedom of opinion and expression, including the freedom 'to seek, receive, and impart information and ideas through any media and regardless of frontiers,' in accordance with Article 19 of the Universal Declaration of Human Rights." Id. at 210. Finally, the "U.S. Supreme Court also recognized many of these principles. ..." Id. (citing Red Lion Broadcasting Co. v. FCC, 395 U.S. 367, 390 (1969)).

${ }^{130}$ See BLANCHARD, supra note 10, at 99-154 (exploring the overlap between postWorld War II free-press promotion efforts and the United States' post-war propaganda).

131Stanley v. Georgia, 394 U.S. 557, 564 (1969).

${ }^{132} I d$.

${ }^{133}$ Houchins v. KQED, Inc., 438 U.S. 1, 11 (1978).
} 
cle 19 of the Universal Declaration of Human Rights, for example, says the right to freedom of opinion and expression includes the right "to seek, receive and impart information and ideas through any media and regardless of frontiers." 134 This wording is reiterated in Article 13 of the American Convention on Human Rights, which the United States has signed but not ratified: "Everyone has the right to freedom of thought and expression. This right includes freedom to seek, receive, and impart information and ideas of all kinds, regardless of frontiers, either orally, in writing, in print, in the form of art, or through any other medium of one's choice."135

Many courts around the world, especially international human rights tribunals, have stated explicitly that the right of expression also includes the right of access to information. ${ }^{136}$ For example, the Inter-American Court of Human Rights recently noted that Article 13 of the American Convention on Human Rights protects the rights of the individual to express messages as well as the rights of members of society to receive messages. 137 While these decisions do not necessarily mandate the conclusion that there is a fundamental right of access to government-controlled information, the international law community's heightened awareness of the right to receive information would be beneficial in Supreme Court jurisprudence because it would bring U.S. law more in line with current conditions in international information flow. 138

\section{Conclusion: The Continuing Viability of SMith-MundT}

The Smith-Mundt Act's ban on domestic dissemination of the government's international propaganda is entirely unenforceable. The federal government could perhaps attempt some technologicallybased enforcement mechanism such as blocking from its international propaganda Web sites all IP addresses known to originate within the

\footnotetext{
134 Universal Declaration of Human Rights, G.A. Res. 217A (III), U.N. Doc. A/810 (1948).

${ }^{135}$ American Convention on Human Rights, Nov. 22, 1969, art. 1.1, 1144 U.N.T.S. 123.

${ }^{136}$ See, e.g., Caso Herrera Ulloa v. Costa Rica, 107 Inter-Am. Ct. H.R. (ser. C), at 56 (2004).

${ }^{137} \mathrm{Id}$.

${ }^{138}$ See Gormly, supra note 129, at 210-11 ("The USIA domestic dissemination ban fails to meet these principles. Central to the ban is a distinction between information available within the United States and that obtained outside the country, a recognition of national frontiers that violates both the letter and the spirit of the Universal Declaration of Human Rights and its expressions in American law.") (footnotes omitted).
} 
United States, but that solution would not guarantee the result sought. Some Internet users within the United States undoubtedly would be able to use proxy addresses, or otherwise circumvent any blocking mechanism, and even if not, the government's propaganda materials also may already be accessed via satellite television or overthe-air broadcasts in some areas of the United States. Additionally, any U.S. citizen interested in accessing internationally targeted propaganda could easily do so by requesting it from contacts in other countries or by traveling abroad and gaining access to it personally.

Of course, the federal government may be satisfied with doing its best to prevent international propaganda materials from being accessed within the United States but passively allowing it to happen if it is considered unavoidable. In that case, at least, the government would not be seen as an aggressive propagandist, given that any U.S. citizen who accessed the materials would have done so only despite the government's best effort to prevent it, and the post-World War II worries that accompanied adoption of the ban would be at least partially assuaged. Still, as more and more U.S. international propaganda materials become available within the country's own borders, the domestic dissemination ban will become increasingly difficult to justify and defend.

It is apparent that while the federal government publicly adheres to the domestic dissemination ban by telling people like Michael Gartner that they cannot photocopy documents they can otherwise view in government offices, ${ }^{139}$ government nevertheless engages in a substantial amount of domestic propaganda. In early 2005, for example, President Bush vowed to bring an end to his administration's practice of surreptitiously paying political commentators and journalists to promote government policies. ${ }^{140}$ Concerns with surreptitious government propaganda were heightened with the 2005 report that twenty federal agencies in the Bush Administration produced and distributed to local television stations hundreds of pre-packaged video news segments (video news releases). ${ }^{141}$ Many of these news releases were broadcast "without any acknowledgement of the gov-

\footnotetext{
${ }^{139}$ Gartner v. United States Info. Agency, 726 F. Supp. 1183 (S.D. Iowa 1989). The Gartner case illustrates that the Smith-Mundt Act's domestic dissemination ban is not about preventing access to certain government speech because Gartner, like other journalists, researchers and members of Congress, was not barred by the act from accessing international propaganda materials. Rather, the act was interpreted to bar the dissemination of those materials-even by someone other than the government itself.

${ }^{140}$ See Kurtz, supra note 121 , at A4.

${ }^{141}$ See David Barstow \& Robin Stein, Under Bush, a New Age of Prepackaged TV News, N.Y. TIMES, Mar. 13, 2005, at A1.
} 
ernment's role in their production[,]"142 prompting the creation of a public effort-centered around an Internet-based effort called "Stop Fake News" - to craft "citizen agreements" in which local television outlets would agree not to use government-produced video news. ${ }^{143}$ If the Smith-Mundt Act's domestic dissemination ban merely forces government propaganda efforts underground, then perhaps the ban should be repealed so that, if American citizens are to be exposed to government propaganda, at least the source and motivation of those messages will be clear. 144

Given the technological difficulties involved in preventing the flow of information across borders, Congress should reassess the policy behind the domestic dissemination ban in the Smith-Mundt Act. Perhaps the ban made sense amid Cold War fears about too much internal propaganda and too little external propaganda. But that era has passed, and the near-impossibility of enforcing the ban in contemporary society-not to mention Congress' selective repeal of the ban in numerous instances where the international propaganda materials were apparently adjudged appropriate for domestic audiences-should be cause for reflection about whether the ban remains desirable. For a decade, commentators have observed that it is not good policy for the U.S. government to prevent its own citizens from receiving messages produced at public expense that are aimed to tell the rest of the world who we are and what we believe. 145

${ }^{142} I d$.

${ }^{143} \mathrm{At}$ least two Web sites dedicated to the cause were created in the wake of a Mar. 13, 2005, New York Times report. See http://www.stopfakenews.org (last visited June 25, 2005) and http://www.freepress.net/action/fakenews (last visited June 25, 2005). A group called "Media for Democracy" began to circulate an e-mail floating the idea of the "citizen agreements" with broadcasters. Meanwhile, a petition on the Internet called on broadcasters to at least disclose the goverrnment's role in producing news releases. See http://www.freepress.net/action/fakenews (last visited June $25,2005)$.

${ }^{144}$ This conclusion relates to the idea expressed by D.C. Circuit Judge David Tatel in his dissent in Essential Information, Inc. $v$. United States Information Agency, 134 F.3d 1165 (D.C. Cir. 1998). Judge Tatel argued that there would not be a danger of undue influence through propaganda if the government merely passively responded to a Freedom of Information request seeking access to international propaganda materials. Id. at 1170 (Tatel, J., dissenting).

${ }^{145}$ See Schwartz, supra note 56 (quoting former FCC commissioner Newton Minow and Annenberg Fellow Alvin Snyder, who wrote in 1994: "Shouldn't we have the opportunity to know what the United States is saying to people in Bosnia, Russia or South America. ... Yesterday's fear that such programs will 'brainwash' the American public is senseless. We get a steady stream of government views in speeches, briefings and press releases, and we are capable of reaching our own conclusions."); Kathy R. Fitzpatrick, Telling America's Story, 70 Vital SpeEches of THE DAY 412 (Apr. 15, 2004) ("Let's not forget that-like military, education and other government programs-public diplomacy is supported by U.S. taxpayer dol- 
Beyond the technological imperative, Supreme Court jurisprudence that seems increasingly willing to suggest the government has a virtually unrestricted right to speak and, by extension, not to speak, may be in conflict with the long-standing U.S. advocacy of open information flow across international borders. It seems that an unstated reason for court decisions upholding Smith-Mundt's domestic dissemination ban against challenges based on the First Amendment and on the Freedom of Information Act ${ }^{146}$ may be that U.S. courts are reluctant to narrowly define the federal government's right to speak and its right not to speak. Thus, the government speech doctrine appears to be on a collision course with the right to send and receive information freely. Ultimately, the United States will have to choose between the traditional model of restricting information flow based on geographical borders or demonstrating a true commitment to free and open information flow, including within its own borders with respect to international propaganda materials now banned by Smith-Mundt.

In order to avert the potentially colossal clash between the government speech doctrine and the free flow of information doctrine, lawmakers and jurists in the United States should realize that the country's renewed efforts to promote democracy and transparency in governments around the world ${ }^{147}$ may be seen as duplicitous and insincere if the U.S. government itself is not transparent with its own citizens. While some dicta in several Supreme Court cases seems to suggest the outer limits on the government's right to speak (or not speak) are set by the political process, there are other important limits as well. The Freedom of Information Act broadly stands for the proposition that any information in the possession of government officials is presumed to be publicly accessible unless specifically designated otherwise-for cause-by statute. 148 More importantly, the

lars. That means that in terms of public diplomacy, you-we-are effectively the publishers of America's story.”).

${ }^{146}$ See supra notes 68-97 and accompanying text.

${ }^{147}$ In his second inaugural address on January 20, 2005, President Bush attempted to make a case for the United States as the promoter of democracy worldwide: "The enemies of liberty and our country should make no mistake: America remains engaged in the world by history and by choice, shaping a balance of power that favors freedom. We will defend our allies and our interests. We will show purpose without arrogance. We will meet aggression and bad faith with resolve and strength. And to all nations, we will speak for the values that gave our nation birth." See White House, President George W. Bush's Inaugural Address (2005), at http://www.whitehouse.gov/news/inaugural-address.html.

${ }^{148}$ See Gormly, supra note 129, at 214 (citing authorities to support the proposition that federal law recognizes that the default position in government document access is openness, and any departure from that position must be justified); 
courts have underappreciated the constitutional bases for public access to government information.

The Supreme Court has recognized that some protection for newsgathering is necessary if the speech and press clauses of the First Amendment are to be effective. ${ }^{149}$ While no federal constitutional provision specifically recognizes a public right to access government information, the converse is also true: No constitutional provision specifically precludes the existence of such a right. Given the Ninth and Tenth amendments' reservation of all rights not otherwise delegated to the people and to the states, it is not unreasonable to conclude that the First Amendment's categorical statement that Congress ${ }^{150}$ shall make no law abridging freedom of speech or of the press also means that Congress may not act to inhibit public access to government information.

Such an interpretation of the federal Constitution is bolstered by the international community's sense of importance of the right to receive information without undue restriction. ${ }^{151}$ While there is a substantial current debate among the justices of the Supreme Court about whether international legal materials have any relevance to U.S. Supreme Court jurisprudence, 152 the right to receive information squares with today's reality of flow of information across international borders. If one of the primary purposes of the speech protections in the First Amendment is to facilitate the functioning of rational choices in democracy, then today that purpose is best accomplished by ensuring the widest access possible to information. In the age of the Framers of the Constitution, it may have been enough to protect the right of the press to be free from prior restraint, but the Internet allows everyone to participate directly in the democratic process by accessing information that allows decision making and participation in public processes.

Schoenhard, supra note 55, at 498-99 (citing authorities to support the proposition that federal law recognizes that the default position in government document access is openness, and any departure from that position must be justified).

${ }^{149}$ Branzburg v. Hayes, 408 U.S. 665, 681, 707 (1972).

${ }^{150}$ The First Amendment was incorporated against the states by virtue of the Fourteenth Amendment. See Gitlow v. People of State of New York, 268 U.S. 652, 666 (1925).

151See supra notes 134-37 and accompanying text.

${ }^{152}$ On January 13, 2005, Justices Antonin Scalia and Stephen Breyer engaged in a vigorous debate at American University's Washington College of Law in Washington, D.C., on the issue of whether the Supreme Court should cite foreign court decisions in its opinions. See Transcript at http://domino.american.edu/AU/media/ mediarel.nsf/1D265343BDC2189785256B810071F238/1F2F7DC4757FD01E85256 F890068E6E0?OpenDocument. 
These conclusions do not mean to imply that the U.S. government should be forced into disseminating domestically all of its international propaganda. But, if taxpayers who fund the production of international propaganda desire to view the materials for themselves and initiate a request under the Freedom of Information Act, the government should not be allowed to keep the materials shrouded in secrecy. As long as the information produced in response to such requests were clearly labeled as international propaganda by the U.S. government, there would be little risk of subverting the marketplace of ideas because citizens could decide for themselves the value and meaning of the government messages. ${ }^{153}$ This contention is supported by the fact that Congress already has mandated that international propaganda materials be released publicly after twelve years. 154

New information technologies are prime movers of social and political change in public diplomacy. 155 Provisions of the Smith-Mundt Act formulated in the post-World War II period no longer make sense today, particularly in view of the pervasiveness of the Internet. It is no longer possible to narrowly target domestic or international audiences by geography for propaganda purposes. In the face of these advancing technologies, restricting domestic use of international public diplomacy materials will continue to generate new questions and challenges as long as Congress fails to modify or repeal its outdated domestic dissemination ban. 156

${ }^{153}$ This is the very rationale relied on by Congress in adopting the Foreign Agents Registration Act, the statute challenged in Meese v. Keene, 481 U.S. 465 (1987). Congess stated that the law, which requires the labeling of certain foreign films as "political propaganda," was passed in order to

$[\mathrm{P}]$ rotect the national defense, internal security, and foreign relations of the United States by requiring public disclosure by persons engaging in propaganda activities and other activities for or on behalf of foreign governments, foreign political parties, and other foreign principals so that the Government and the people of the United States may be informed of the identity of such persons and may appraise their statements and actions in the light of their associations and activities.

56 Stat. 248-248 (quoted in Meese, 481 U.S. at 469).

${ }_{154}$ See supra note 43 and accompanying text.

${ }^{155}$ See generally Richard BuRT, OLIn ROBISON \& BARRY Fulton, CEnTER FOR StRATEGiC AND InT'L Studies, REINVENTING DiplomaCy IN THE INFORMATION AGE: A Report of the CSIS Advisory PANEL ON DiplomaCy IN THE INFORMATion AGE (1988) (advocating the improvement of U.S. diplomacy through replacement of obsolete technology and involvement of a larger community of international and domestic organizations and individuals).

156See Stephen Johnson \& Helle Dale, The Heritage Foundation, How to Reinvigorate U.S. Public Diplomacy: BaCKGrounder \# 1645 (2003), at http:// www.heritage.org/Research/NationalSecurity/bg1645.cfm. 